\title{
Productivity of cotton and sorghum in an agroforestry system of shea trees (Vitellaria paradoxa gaertn) in northern Benin
}

\author{
Césaire Paul Gnanglè ${ }^{1^{*}}$, Charlemagne Gbemavo ${ }^{2}$, Kouèssi Aïhou ${ }^{1}$, Romain Glèlè Kakaï ${ }^{2}$, \\ Nestor Sokpon ${ }^{3}$ \\ ${ }^{1}$ National Institute of Agricultural Research of Benin, Central Agricultural Research Centre, Forest Research Programme, Savè, \\ Benin; *Corresponding Author: gnampaces@yahoo.fr \\ ${ }^{2}$ School of Agricultural Sciences, University of Abomey, Cotonou, Benin \\ ${ }^{3}$ School of Agriculture, University of Parakou, Parakou, Benin
}

Received 26 September 2012; revised 28 October 2012; accepted 10 November 2012

\begin{abstract}
This study evaluates the productivity of cotton and sorghum in a shea-based agroforestry system in northern Benin. Tomboutou and Gounarou villages were respectively selected in the shea parklands of Bembèrèkè and Kandi. Within each parkland and village, three classes of tree crown diameter for shea trees (4-8 m, 8 - $10 \mathrm{~m}$ and $<10 \mathrm{~m}$ ), were defined after the inventory phase. In each class of crown diameter, three trees intercropped with cotton and sorghum were randomly selected among the 18 to 21 farms in each of the two village territories. The crops were planted in accordance with the technical procedures recommended by the national agricultural extension service. The following data was collected for sorghum and cotton on 1 $\mathrm{m}^{2}$ area under the crown and outside the crown, in the four cardinal directions of each sample tree: crop height, fresh biomass per crop and buds per cotton plant. Data analysis revealed a very significant difference in the variables (height of sorghum and cotton, biomass of cotton and sorghum, number cotton buds) between the areas under the crown and those outside the crown $(P<0.01)$. The productivity variables for sorghum, i.e., average plant height and average biomass, dropped by $9.75 \%$ and $29.31 \%$, respectively, when planted under the crown. Cotton under the crown was $6.58 \%$ shorter compared to plants outside the crown. Average bud production and average fresh biomass for cotton plants was $13.06 \%$ and $36.06 \%$ less, respectively, when planted under the crown of shea trees.
\end{abstract}

Keywords: Ecophysiology; Productivity;
Agrosystem; Cotton; Sorghum; Shea Tree; Shade-Tree Management; Benin

\section{INTRODUCTION}

The presence of trees among crops creates landscapes known as "agroforestry landscapes" [1]. The benefit of integrating trees into farming systems has been highlighted [2,3]. Shea parklands, for instance, help maintain soil fertility and the sustainability of cropping systems [4]. In fact, the biomass produced by the trees is broken, allowing recycling of nutrients pumped by the shaft depth horizons to the surface soil. In Benin, the combination of shea with other crops on shea parklands is common [5]. The effects of intercropping shea trees with other crops appears to be contradictory. According to some authors [3], crop yields are better [1] or worse [6,7] under the tree's zone of influence. The combination of cotton, sorghum and shea is one of the most common farming systems in northern Benin [8]. Cotton and shea nuts contribute considerably to the country's economy and are first and third among export products, respectively. Sorghum ensures food security for much of the population and is one of the most cultivated cereals in the study area. It is therefore necessary to conserve this tree-cropping system and improve its productivity. In Africa, research has been carried out on the subject, namely by [1] in Burkina Faso, [9] on the influence of shea on crop yields in Côte d'Ivoire; and [10] on the influence of Faidherbia albida on cotton in Cameroon. In Benin, [7] has studied the influence of shea tree shading on cotton yields. The influence of shea tree shading on plant height and yield of other crops other than cotton is not known. The objective of this study is to assess the influence of the shea tree crown on productivity (height, yield, fresh biomass) of cotton and sorghum in northern Benin. 


\section{METHODOLOGY}

\subsection{Study Environment}

The study was conducted in two villages in two communes (Figure 1.) in the northern Benin: Gounarou (10 47'655"N and $\left.2^{\circ} 48^{\prime} 610^{\prime \prime} \mathrm{E}\right)$ in Gogounou commune and Tomboutou (11 $84^{\circ} 306^{\prime \prime} \mathrm{N}$ and $\left.3^{\circ} 24^{\prime} 966^{\prime \prime} \mathrm{E}\right)$ in Malanville commune. The village of Gounarou is characterized by a relatively flat topography, an average annual rainfall of $1200 \mathrm{~mm}$ distributed over a rainy season from May to October and an average crop cycle of 150 days. The temperature ranges between $18^{\circ} \mathrm{C}$ and $38^{\circ} \mathrm{C}$ especially in the dry season. Gogounou commune is watered by two (02) major rivers and their tributaries belonging to the Niger River Basin. It is the Sota and Alibori located respectively in the East and the West. Soils are those of gneissic granite base for most ferruginous and generally suitable for agriculture. In floodplains, alluvial soils dominate, clayey-sandy rich enough due to the addition of organic matter by the annual high water rivers. The main crops in Gounarou are cotton, maize, sorghum, yams; livestock products are also prevalent. Fallow periods last from 5 to 10 years or more. The Bariba are the dominant ethnic group.

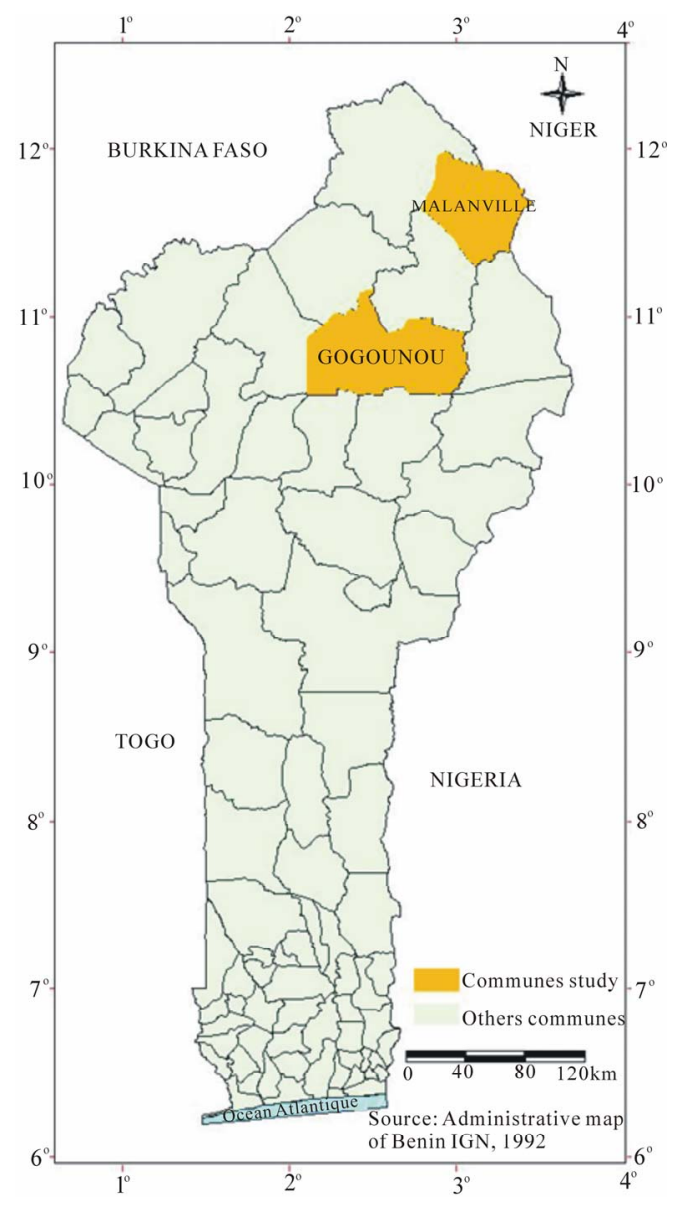

Figure 1. Study area.
The village Tomboutou has a more open landscape, characteristic of the Sahel. Average annual rainfall is 900 $\mathrm{mm}$ with a cropping period of 120 days. The temperature varies from $16^{\circ} \mathrm{C}$ to $20^{\circ} \mathrm{C}$. The Malanville commune soils are more tropical ferruginous soils or less hydromorphic sol developed on the sandstone or alluvium of Niger. Some very gravelly ferruginous tropical soils and raw mineral soils on armor are also found in the commune. The area is dominated by cereal production: rice, sorghum, millet. Groundnuts, market vegetables (tomatoes, peppers, okra, potato, onion), cotton and cassava are cultivated. Livestock production and fishing is also common. Crops are harvested from November to December or January, and crop residues (sorghum and cotton stalks) are left on the field for grazing. Large quantities of sorghum straw are harvested for domestic use (fences, soap production). Pressure on natural resources is evident in Tomboutou, where fallow periods are very short (1 - 2 years) and conflicts between farmers and herders frequent. Tomboutou borders the international market of the Commune of Malanville, which sees a great deal of market activity.

\subsection{Influence of Shea on Productivity of Cotton and Sorghum}

\subsubsection{Experimental Design and Data Collection}

The experimental design consists of shea trees, cotton and sorghum. Two criteria were used to select sample shea trees: the combination of shea with cotton or sorghum in more or less homogeneous soils, and the width of the tree crown, broken down into three categories of crown diameter: 4 - 8 metres; 8 - 10 metres and $<10$ metres. A local variety of sorghum called red sorghum (dobi in Bariba) was used in Gounarou; early white sorghum (henniwasso in Dendi) was used in Tomboutou. The cotton variety grown in the two villages was the improved variety $\mathrm{H} 279-1$, sown at $0.80 \mathrm{~m}$ on the row and $0.40 \mathrm{~m}$ between rows and thinned to two plants per hill. The spacing of the sorghum plants is $1 \mathrm{~m}$ on the row and 0.90 $\mathrm{m}$ between rows; they were not thinned. In each crown category, 3 trees intercropped with cotton and sorghum were randomly selected among the 18 to 21 farms in each of the two villages. In all, nine trees were used for experimentation, per crop and per village.

A North-South transect and East-West transect were created around each sample tree. The transects demarcated two zones of shade influence: the area under the crown and outside the crown. Data was collected with a radius of $0.5 \mathrm{~m}$ from the crown and $1.5 \mathrm{~m}$ from the crown (Figure 2). Thus, at each measuring position, a 1 $\mathrm{m}$ square was demarcated, to measure the cotton and sorghum plants. Data was collected for plant height of cotton and sorghum, biomass weight of residues per crop and the number of cotton buds. 


\subsubsection{Statistical Analysis}

Variables were subjected to analysis of variance, partial hierarchical model with 5 factors including: site or village (fixed factor), crown category (fixed factor), distance from tree (fixed factor), direction (fixed factor), sorghum or cotton plant (subordinate to the four other factors). Adjusted means were calculated for the different levels of factors and interaction plots were generated for significant interactions between factors.

\section{RESULTS}

\subsection{Influence of the Tree Crown on Sorghum Productivity}

ANOVA results for the effects of various factors on sorghum yields revealed highly significant differences between the factors Site and Position, as regards the height of sorghum plants and fresh biomass (Table 1). The crown diameter and direction of the sorghum plant have no significant effect on plant height but do significantly influence the amount of fresh biomass. Table 2 presents the means of the various productivity parameters for sorghum, according to the different positions (outside the influence and under the influence). This table reveals that, because of their crown, shea trees reduce sorghum yields under canopy in shea parklands. Indeed the average height of sorghum plants is reduced by $9.75 \%$, while fresh biomass is reduced by $29.31 \%$. The influence of the shea tree canopy on sorghum height depends on the diameter of the crown and vice versa (Table 1). This interaction crown diameter $(\mathrm{m})$ and position is illustrated in Table 3. This table shows significantly higher heights for plants outside the crown's zone of influence $(3 r / 2)$ than those under the influence $(\mathrm{r} / 2)$.

A description of the effects of the different interactions is presented in Figure 3. This figure reveals that fresh biomass per $\mathrm{m}^{2}$ is greater in Tomboutou than Gounarou. Also, plants located in the shea tree's zone of influence are generally less productive than those located outside the zone. However, the crown diameter is influenced by the site: in Gounarou, the effect of the crown's width on sorghum yields is negligible while in Tomboutou, plant biomass increases with the average width of the shea tree

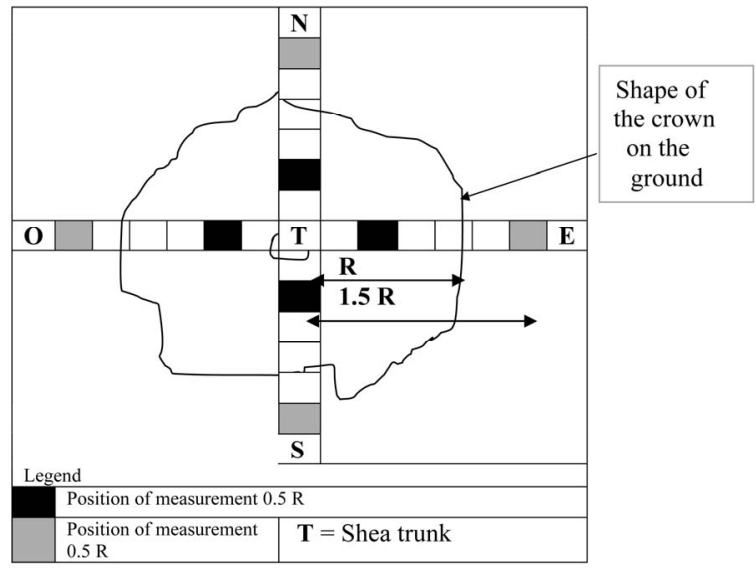

Figure 2. Experimental design for data collection.

Table 1. Results of the five-factor analysis of variance for sorghum plant height and fresh biomass.

\begin{tabular}{|c|c|c|c|c|c|}
\hline \multirow{2}{*}{ Source } & \multirow{2}{*}{ d.f. } & \multicolumn{2}{|c|}{ Plant height (m) } & \multicolumn{2}{|c|}{ Fresh biomass $\left(\mathrm{g} / \mathrm{m}^{2}\right)$} \\
\hline & & MS & $\mathrm{F}$ & MS & $\mathrm{F}$ \\
\hline Site (S) & 1 & 1255130.89 & $154.57^{* * *}$ & 54164346.36 & $685.15^{* * *}$ \\
\hline D (Crown diameter) & 2 & 16764.68 & $2.06 \mathrm{~ns}$ & 1441106.85 & $18.23^{* * *}$ \\
\hline Po (Position) & 1 & $352,091.05$ & $43.36^{* * *}$ & 12274456.28 & $155.27^{* * *}$ \\
\hline O (Direction) & 3 & 6039.39 & $0.74 \mathrm{~ns}$ & 728806.50 & $9.22^{* * *}$ \\
\hline $\mathrm{T}(\mathrm{S} \times \mathrm{D} \times \mathrm{O} \times)$ & 471 & 7701.29 & $0.95 \mathrm{~ns}$ & 43630.20 & $0.55 \mathrm{~ns}$ \\
\hline $\mathrm{Po} \times \mathrm{O}$ & 3 & 25913.56 & $3.19 \mathrm{~ns}$ & 109639.05 & $1.39 \mathrm{~ns}$ \\
\hline $\mathrm{D} \times \mathrm{Po}$ & 2 & 16703.89 & $2.06^{* * *}$ & 494438.13 & $6.25^{* *}$ \\
\hline $\mathrm{S} \times \mathrm{D}$ & 2 & 193618.25 & $23.84 \mathrm{~ns}$ & 2180958.90 & $27.59^{* * *}$ \\
\hline $\mathrm{S} \times \mathrm{Po}$ & 1 & 6483.13 & $0.80 \mathrm{~ns}$ & 925491.34 & $11.71^{* * *}$ \\
\hline $\mathrm{D} \times \mathrm{O}$ & 6 & 14614.29 & $1.80 \mathrm{~ns}$ & 160270,05 & $2.03 \mathrm{~ns}$ \\
\hline $\mathrm{S} \times \mathrm{D} \times \mathrm{Po}$ & 2 & 23772.15 & $2.93 \mathrm{~ns}$ & 192211.23 & $2.43 \mathrm{~ns}$ \\
\hline $\mathrm{S} \times \mathrm{Po} \times \mathrm{O}$ & 3 & 5656.90 & $0.70 \mathrm{~ns}$ & 430744.43 & $5.45^{* *}$ \\
\hline $\mathrm{S} \times \mathrm{Po} \times \mathrm{O}$ & 6 & 30103.17 & $3.71 \mathrm{~ns}$ & 252187.21 & $3.19^{*}$ \\
\hline $\mathrm{S} \times \mathrm{D} \times \mathrm{Po} \times \mathrm{O}$ & 12 & 13376.40 & $1.65 \mathrm{~ns}$ & 394856.19 & $4.99^{* * * *}$ \\
\hline
\end{tabular}

*Significant difference at $\mathrm{P}=0.05,{ }^{* *}$ Significant difference at $\mathrm{P}=0.01,{ }^{* * *}$ Significant difference $\mathrm{P}=0.001$, ns not significant. T: Sorghum stalk. 
Table 2. Adjusted mean and standard error (se) of plant height and fresh biomass for sorghum according to the position.

\begin{tabular}{|c|c|c|c|c|}
\hline \multirow{2}{*}{ Position } & \multicolumn{2}{|c|}{ Outside the influence } & \multicolumn{2}{|c|}{ Under the influence } \\
\hline & $\mathrm{m}$ & se & $\mathrm{m}$ & se \\
\hline Parameters Height (cm) & 375.8 & 3.38 & 339.2 & 4.76 \\
\hline Fresh biomass $\left(\mathrm{g} / \mathrm{m}^{2}\right)$ & 571.4 & 14.49 & 403.9 & 17.75 \\
\hline
\end{tabular}

Table 3. Adjusted mean and standard error (se) of plant height for sorghum ( $\mathrm{H}$ in $\mathrm{cm}$ ) according to the crown diameter and position.

\begin{tabular}{cccc}
\hline \multirow{2}{*}{ Crown diameter $(\mathrm{m})$} & Position & \multicolumn{2}{c}{ Height $(\mathrm{cm})$} \\
\cline { 2 - 4 } & & $\mathrm{m}$ & $\mathrm{Se}$ \\
\hline 4_8 & $\mathrm{r} / 2$ & 353.66 & 7.66 \\
$8 \_10$ & $\mathrm{r} / 2$ & 343.64 & 9.75 \\
$>10$ & $\mathrm{r} / 2$ & 351.85 & 11.10 \\
$4 \_8$ & $3 / 2 \mathrm{r}$ & 381.80 & 6.54 \\
$8 \_10$ & $3 / 2 \mathrm{r}$ & 387.64 & 7.10 \\
$>10$ & $3 / 2 \mathrm{r}$ & 403.34 & 8.44 \\
\hline
\end{tabular}

canopy. This latter observation holds true regardless of the position of the sorghum plants and their direction relative to the tree.

\subsection{Influence of the Tree Crown on Cotton Productivity}

Table 4 presents ANOVA results for the effects of different factors on the height of cotton plants, the number of buds and fresh biomass. This table shows that all the parameters vary significantly according to the various factors except the direction of the plants, which does not affect plant height. Table 5 presents the means of the various productivity criteria for cotton, according to the different positions (outside the influence and under the influence). This table shows that because of their crown, shea trees reduce cotton bud yields under canopy in sheaparklands in Gounarou and Tomboutou in northern Benin. Indeed the average height of cotton plants is reduced by $6.58 \%$ under the crown's influence, while the number of buds per plant drops $13.06 \%$ and fresh biomass reduces by $36.06 \%$. Moreover, only the paired interactions site with crown diameter and site with plant position are significant, as well as crown diameter with direction.

A description of the statistically significant interactions is shown in Figure 4. In Tomboutou, crown diameter

Table 4. Results of five-factor analysis of variance for five plant height, number of buds and fresh biomass for cotton.

\begin{tabular}{|c|c|c|c|c|c|c|c|}
\hline \multirow{2}{*}{ Source } & \multirow{2}{*}{ d.f. } & \multicolumn{2}{|c|}{ Plant height (m) } & \multicolumn{2}{|c|}{ Number of buds } & \multicolumn{2}{|c|}{ Fresh biomass $\left(\mathrm{g} / \mathrm{m}^{2}\right)$} \\
\hline & & MS & $\mathrm{F}$ & MS & $\mathrm{F}$ & MS & $\mathrm{F}$ \\
\hline S (Site) & 1 & 57313.67 & $143.25^{* * *}$ & 131.64 & $10.67^{* *}$ & 3617771.59 & $2591.43^{* * *}$ \\
\hline D (Crown diameter) & 2 & 11014.08 & $27.53^{* * *}$ & 154.12 & $12.50^{* * *}$ & 122701.65 & $87.89^{* * *}$ \\
\hline O (Direction) & 3 & 477.07 & $1.19 \mathrm{~ns}$ & 74.39 & $6.03^{* * *}$ & 47827.33 & $34.26^{* * *}$ \\
\hline $\mathrm{T}(\mathrm{S} \times \mathrm{D} \times \mathrm{O} \times \mathrm{Po})$ & 346 & 400.11 & $0.89 \mathrm{~ns}$ & 12.33 & $0.85 \mathrm{~ns}$ & 1396.05 & $0.38 \mathrm{~ns}$ \\
\hline $\mathrm{S} \times \mathrm{D}$ & 2 & 8943.93 & $22.35^{* * *}$ & 353.71 & $28.68^{* * *}$ & 126210.88 & $90.41^{* * *}$ \\
\hline $\mathrm{S} \times \mathrm{O}$ & 3 & 890.37 & $2.23 \mathrm{~ns}$ & 47.87 & $3.88^{* *}$ & 69150.29 & $49.53^{* * *}$ \\
\hline $\mathrm{P} \times \mathrm{O}$ & 3 & 656.42 & 1.64 ns & 20.64 & $1.67 \mathrm{~ns}$ & 37742.14 & $27.03^{* * *}$ \\
\hline $\mathrm{D} \times \mathrm{O}$ & 6 & 1310.92 & $3.28^{* *}$ & 13.55 & $1.10 \mathrm{~ns}$ & 21383.55 & $15.32^{* * *}$ \\
\hline $\mathrm{D} \times \mathrm{Po}$ & 2 & 23.52 & $0.06 \mathrm{~ns}$ & 76.36 & $6.19^{* *}$ & 16974.32 & $12.16^{* * *}$ \\
\hline $\mathrm{S} \times \mathrm{D} \times \mathrm{Po}$ & 2 & 210.28 & $0.53 \mathrm{~ns}$ & 81.39 & $6.60^{* *}$ & 14425.02 & $10.33^{* * *}$ \\
\hline $\mathrm{S} \times \mathrm{Po} \times \mathrm{O}$ & 3 & 689.22 & $1.72 \mathrm{~ns}$ & 25.94 & $2.10 \mathrm{~ns}$ & 23458.34 & $16.80^{* * *}$ \\
\hline $\mathrm{S} \times \mathrm{D} \times \mathrm{Po} \times \mathrm{O}$ & 18 & 946.61 & $2.37^{* *}$ & 9.48 & $0.77 \mathrm{~ns}$ & 25317.11 & $18.13^{* * *}$ \\
\hline
\end{tabular}

${ }^{*}$ Significant difference at $\mathrm{P}=0.05,{ }^{* *}$ Significant difference at $\mathrm{P}=0.01,{ }^{* * *}$ Significant difference $\mathrm{P}=0.001$, ns not significant. $\mathrm{T}$ : Cotton stem. 
Table 5. Adjusted mean (m) and standard error (se) for plant height and fresh biomass of sorghum according to position.

\begin{tabular}{ccccc}
\hline \multirow{2}{*}{ Position } & \multicolumn{4}{c}{ Outside the influence Under the influence } \\
\cline { 2 - 5 } & $\mathrm{m}$ & $\mathrm{se}$ & $\mathrm{m}$ & $\mathrm{Se}$ \\
\hline Parameters Height $(\mathrm{cm})$ & 94.72 & 0.81 & 88.48 & 0.89 \\
Fresh biomass $\left(\mathrm{g} / \mathrm{m}^{2}\right)$ & 147.70 & 3.01 & 93.53 & 3.29 \\
Number of buds & 6.91 & 0.13 & 6.014 & 0.14 \\
\hline
\end{tabular}

does not have a significant effect on plant height, but the position of the plants does: cotton plants grown outside shea trees' zone of influence are significantly taller. However, in Gounarou, there is no significant effect for the position of plants. In addition, shea trees with larger crown widths $(<10 \mathrm{~m})$ negatively affect the height of cotton plants. With regard to direction, a wide crown is found to negatively affect plant height, except for a western orientation, where the difference is not noticeable.

Figure 5 Illustrates interactions between the different

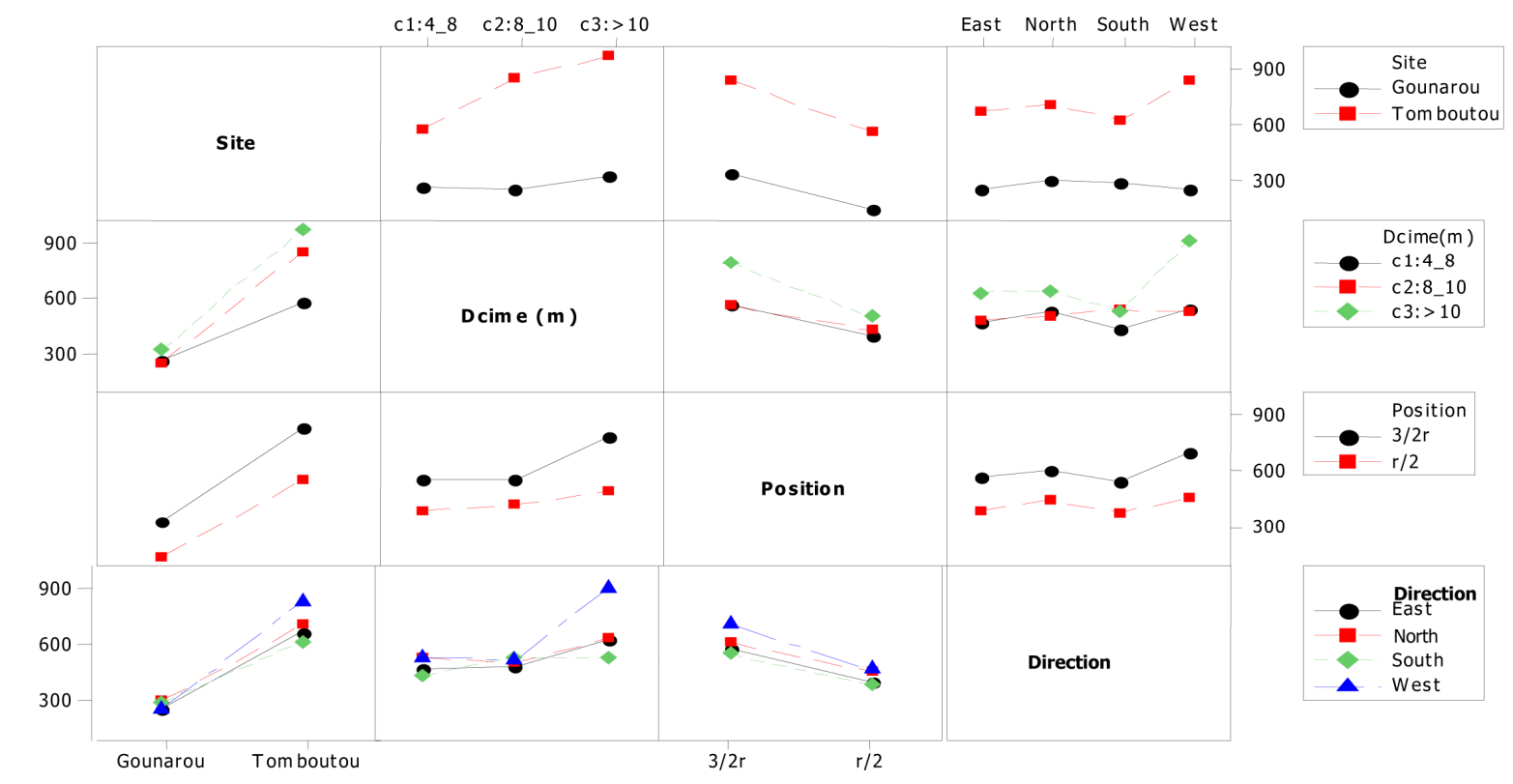

Figure 3. Interaction plot for fresh biomass for sorghum. It appears sorghum plants do best when situated to the west of shea trees.
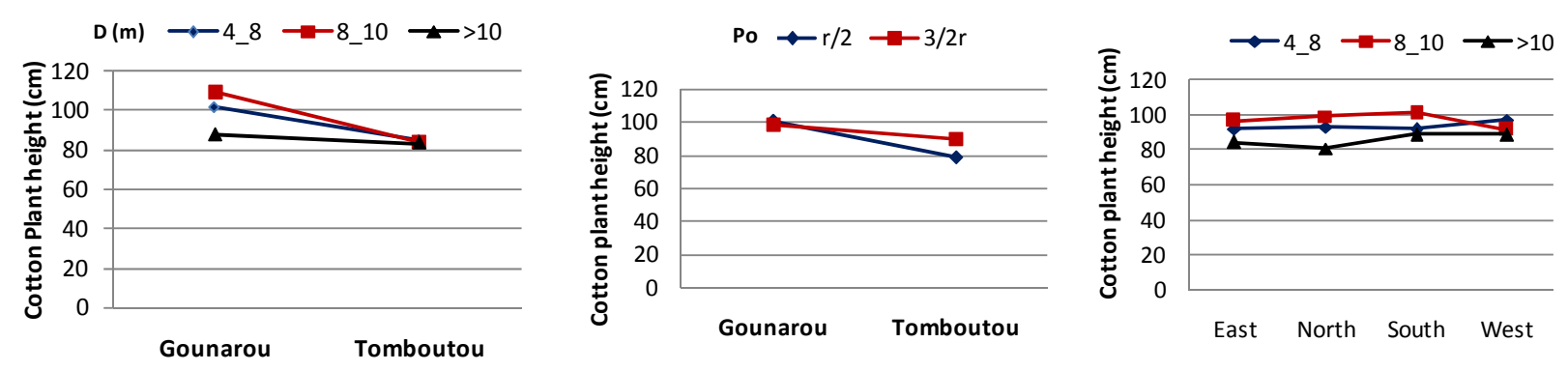

Figure 4. Interaction plots for height of cotton plants (cm).

factors. This figure clearly shows the superiority of fresh biomass $\left(\mathrm{g} / \mathrm{m}^{2}\right)$ for cotton plants in Gounarou, regardless of the other factors. However, there is a decrease of biomass for plants with a western orientation located under the crown's zone of influence. As for the crown width, high values of biomass are associated with trees with an average crown width, regardless of the direction and position of the plants in relation to trees. In Tomboutou, though, the different crown widths have no significant effect on biomass of cotton plants.

Regarding the position of plants in relation to trees, Figure 5 Shows that cotton plants located outside the tree canopy have higher biomass, regardless of the other factors, except in Tomboutou where the two positions result in the same average weight of biomass $\left(73 \mathrm{~g} / \mathrm{m}^{2}\right)$.

\section{DISCUSSION}

Comparison of sorghum and cotton productivity under 


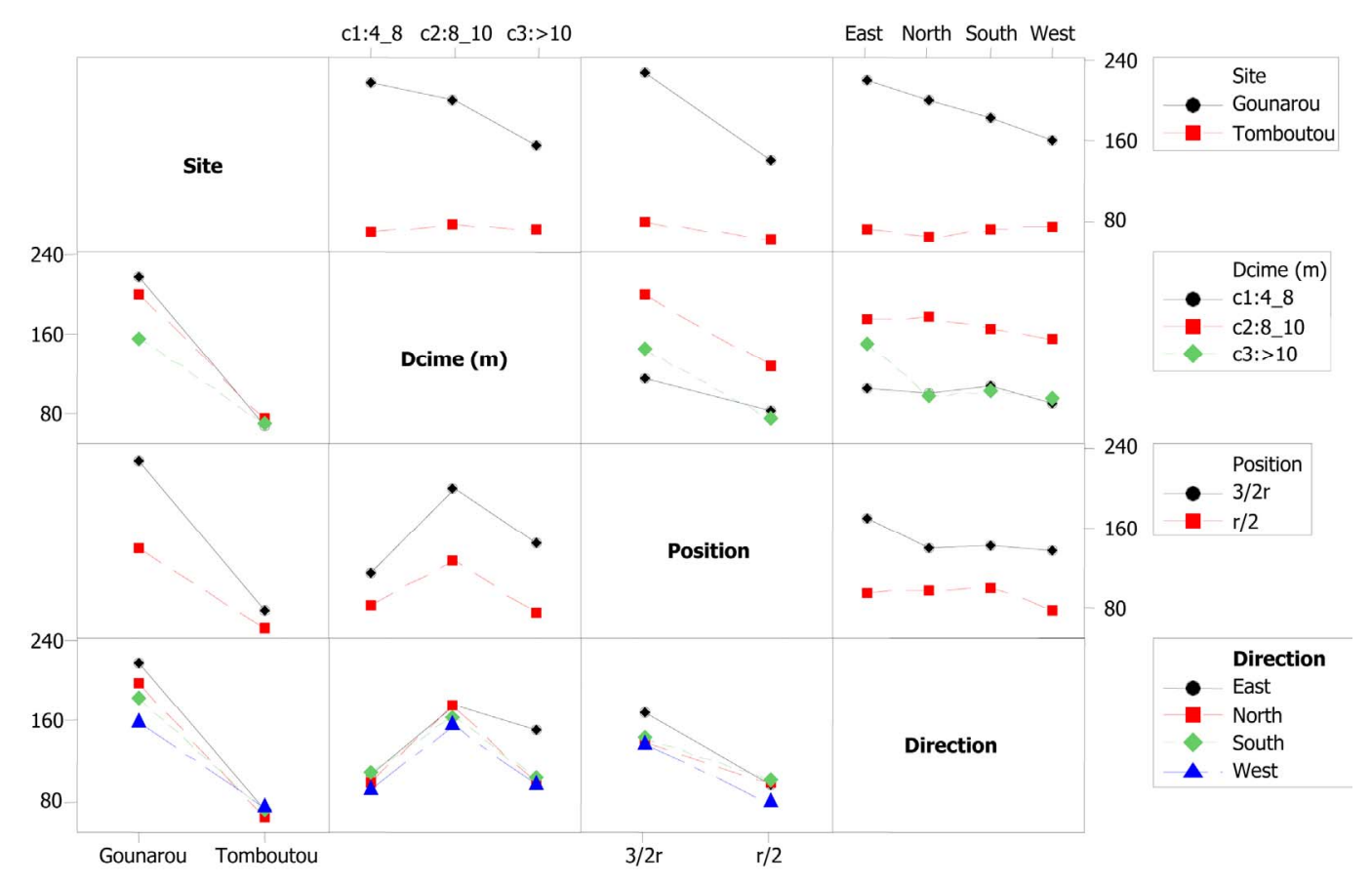

Figure 5. Interaction plot for fresh biomass for cotton.

and outside the shea tree crown This study shows that the shea tree crown has a negative influence on plant height for cotton and sorghum, as well as bud yield for cotton plants. Soil type, water availability and the incidence of solar radiation are the three main factors that may explain the observed variation between cotton and sorghum plants under the canopy and outside the canopy of shea trees. Indeed, there is a marked improvement in soil moisture and soil fertility under the shea tree canopy [1]. The rainfall is, in part, intercepted by the tree canopy and the amount of water reaching the soil under the canopy may not be sufficient, given that the tree and the underlying crop absorb more water than the crop alone [11]. But, the canopy also helps conserve use of soil water [12], as temperatures are moderate under shea trees due to shading [1]. The decrease in crop yields under the shea crown is therefore strongly correlated with the steady decline in light intensity and water found beneath the canopy due to shading. This may be compounded by soil compaction under trees due to animals and men standing under them during the dry season, which can increase runoff and limit the development of cotton seedlings, especially in case of no-till seeding.

Our results are consistent with those of several authors regarding the influence of trees in general and in particular the shea tree on crop yields. Indeed, [7] in an experiment conducted in the town of Kandi, Benin, found that the bud yield of cotton plants decreased by $28.46 \%$ on average under the shea tree canopy. This is double the findings in our study. The difference may be related to cultural practices or differences in the study sites. [1] notes that despite the moisture and soil fertility under tree canopy, maize production remains well below that of plants growing outside the canopy. [9] in Côte d'Ivoire found that the shea tree induced losses in cotton yields (under $3 \mathrm{~kg}$ per tree). Similar observations were found for systems combining sorghum with locust and shea trees; yields declined considerably in plots situated under the canopy [3-6]. In Senegal, [13] found that the locust tree lowers the yield of groundnut pods.

The results of an analysis of seed cotton yields in Faidherbia parklands are more nuanced: Nine of fifteen trees had a positive effect on the crop under the tree and six had a negative effect [10]. This result is an overall positive effect of Faidherbia on cotton yields. The authors have explained this by the fact that Faidherbia albida has a variable effect depending on fertility of the test site; it benefits cotton in poor conditions and impedes it when conditions are better. [9] in Côte d'Ivoire found that the shea tree induces very slight gains in maize and groundnuts on the most fertile plots. These authors agree that the fertility of the test site can reverse the influence of the trees. In their work on crop yields (maize, cotton, groundnuts) under the canopy of shea trees in Burkina Faso, [14] noted that 52\% of farm enterprises and $15 \%$ of peasants interviewed mentioned lower crop yields (millet, fonio, etc.) under the shea canopy. Overall, the effects of tree crop yields appear to be contradictory. The advantage of tree-crop intercropping therefore lies in maintaining soil fertility and the sustainability of farming systems [4], especially since 
many authors have found that shea trees are excellent fertilizers thanks to their leaf biomass. Indeed, studies [2-15] report that trees in fields have positive effects on soil fertility, and especially on levels of organic matter and nitrogen; their areas of influence represent "islands" of fertility in semi-arid zones. Similarly, the work of [16] in Saponé in Burkina Faso showed that mulch from shea leaves induced a $120 \%$ increase in millet grain yields and a $43 \%$ increase in its total dry matter. Shea leaves contribute to soil fertility.

\section{CONCLUSION}

This study has shown that the productivity parameters for sorghum and cotton (plant height, yield and fresh biomass) are higher for plants grown outside the shea tree canopy than those under the canopy. Shea trees in parklands adversely effect crop development under the canopy. To remedy the negative influence of the shea tree canopy, it is important to plant crops that can tolerate the shade. We recommend testing chilli pepper, a very important food crop.

\section{ACKNOWLEDGEMENTS}

The authors would like to thank the Program RIPIECSA, made possible by the French Ministry of Foreign Affairs, for funding this study.

\section{REFERENCES}

[1] Zomboudre, G., Ouedraogo, M., Guinko, S. and Macauley, H.R. (2005) Physiological response and crop productivity in traditional agroforestry system: The case of maize associated with shea butter in the east zone of Burkina Faso. Biotechnology, Agronomy, Society and Environment, 9, 75-85.

[2] Kater, L.J.M., Kante, S. and Budelman, A. (1992) Shea butter and African locust beans trees associated with crops in South Mali. Agroforestry Systems, 18, 89-106. doi:10.1007/BF00115407

[3] Maiga, A. (1987) Trees in traditional agroforestry system in Bazega province. Influence of Vitellaria paradoxa, Parkia biglobosa and Acacia albida on the sorghum and millet. Intership Report, IRBET/CNRST, Ouagadougou, 86.

[4] Traore, K.B. (2003) Shea parklands: Its contribution to the agroecosytem sustainable. Case of a toposequence in Konobougou. Ph.D. Thesis, Soil Science, CIRAD, Montpellier, 216.
[5] Gnanglè, P.C. (2005) Shea parklands in Benin: Sociocultural importance, morphological characterization, structural and natural regeneration. Master Thesis, Management of Natural Resources, UAC/FSA, Abomey-Calavi, 113.

[6] Kessler, J.J. (1992) The influence of shea and African locust beans trees on sorghum production in Burkina Faso. Agroforestry Systems, 17, 97-118. doi:10.1007/BF00053116

[7] Gbemavo, D.S.J.C., Glèlè Kakaï, R., Assogbadjo, A.E., Katary, A. and Gnanglè, P. (2010) Effect of shea trees shadiness on cotton capsular yield in shea butter treescotton agroecosystems of northern Benin. Tropicultura, 28, 193-199.

[8] Agbahungba, G. and Depommier, D. (1989) Shea and African locust beans parklands aspects in southern Borgou. Bois et Forêts des Tropiques, 222, 41-54.

[9] Louppe, D. and Ouattara, N.K. (1997) Shea butter influence on the agricultural production in northern of Ivory Coast. XI ${ }^{\text {th }}$ World Forestry Congress, Antalya, Turkey, Montpellier, CIRAD-Forêt, 13-22 October 1997, 11, 1013.

[10] Libert, C. and Eyog-Matig, O. (1996) Faidherbia albida and cotton production. Faidherbia albida parklands. Cahiers Scientifiques du Cirad-Forêt, 12, 103-122.

[11] Boffa, J.M. (2000) Agroforestry parklands in sub-Saharan Africa. Cahier FAO Conservation, 34, 258.

[12] Akpo, L.E. (1998) Trees effect on herbaceous vegetation in some plant communities in Senegal. Variation along climatic gradient. Ph.D. Thesis, Natural Science, Faculty of Technology Science-University of Cheikh Aanta Diop, Dakar, 133.

[13] Sarr, D. (2001) African locust beans importance in Arachis hypogaea L. culture system in the Nema territory in Sudano-sahelian zone. Master Thesis, University of Cheikh Aanta Diop, Dakar, 37.

[14] Diarassouba, N., Koffi, E.K., N’Guessan, K.A, Van Damme, P. and Sangare, A. (2008) Local knowledge and their use in shea parklands management in Ivory Coast. Africa Focus, 21, 77-96.

[15] Tomlinson, H., Teklehaimanot, Z., Traore A. and Olapade, E. (1995) Soil amelioration and root symbioses of Parkia biglobosa (Jacq.) Benth. in West Africa. Agroforestry Systems, 30, 145-159. doi:10.1007/BF00708918

[16] Bayala, J., Teklehaimanot, Z. and Ouedraogo, J.S. (2002) Millet production under pruned tree crowns in a parkland system in Burkina Faso. Agroforestry Systems, 54, 203214. doi:10.1023/A:1016058906682 